\title{
Peningkatan Kualitas Produk Kerupuk Sari Ikan Melalui Inovasi Produksi
}

\author{
Yelnim $^{1}$, Deky Hamdani ${ }^{1}$, Zachari Abdallah ${ }^{1}$, Ayu Esteka Sari ${ }^{1}$ \\ STIE Sakti Alam Kerinci \\ animstiesak@gmail.com,deky.hamdani@yahoo.com, zachari.abdallah87@gmail.com, ayuesteka82@gmail.com
}

\begin{abstract}
Abstrak
Program Kemitraan Masyarakat Stimulus (PKMS) ini adalah "Usaha Kerupuk Sari Ikan" milik Bapak Saepudin. Usahanya menghasilkan Makanan camilan kerupuk dengan berbagai rasa tetapi yang paling terkenal adalah Kerupuk dengan rasa ikan. Berdasarkan hasil kunjungan lapangan, wawancara, dan pengamatan terhadap Mitra, dapat diidentifikasi beberapa permasalahan prioritas dihadapi mitra diantaranya : a) Untuk proses produksi masih menggunakan alat tradisional, terbatas nya alat yang digunakan sehingga menghambat proses prosuksi. Hal ini ditunjukkan dari : dalam mengerjakan proses produksi kerupuk yang masih sederhana dan masih manual mengakibatkan jumlah produksi dari kerupuk terbatas. Memberikan pelatihan manajemen keuangan dan akuntansi. Berdasarkan permasalahan prioritas yang harus ditangani maka beberapa solusi yang ditawarkan tim PKMS kepada mitra adalah: Bidang produksi dengan Memberikan transfer Teknologi Tepat Guna (TTG) dalam proses produksi berupa mesin Blower yang membantu dalam proses penggorengan dan Gerombong, Bidang Pengemasan dengan memberikan mesin dan alat pengemasan kerupuk sehingga kemasan kerupuk menjadi lebih higienis, Bidang Keuangan dengan memberikan pelatihan dan pendampingan dalam membuat Laporan Keuangan. Hasil dari target luaran PKMS ini adalah : Meningkatkan produktivitas dari Mitra dengan penggunaan mesin proses produksi Kerupuk, Meningkatkan kerapihan dan kehigienisan kemasaan kerupuk dan Meningkatkan pengetahuan Mitra membuat Laporan Keuangan.
\end{abstract}

Kata Kunci : Kualitas Produk, Peningkatan Produksi, Pelatihan Laporan Keuangan, Teknologi Tepat Guna (TTG).

\begin{abstract}
The Stimulus Community Partnership Program (PKMS) is Mr. Saepudin's “Sari Ikan Cracker Business". His business produces cracker snacks with various flavors but the most famous is crackers with fish flavor. Based on the results of field visits, interviews, and observations of partners, it can be identified several priority problems faced by partners including: a) For the production process still using traditional tools, the limited tools used so that hinder the production process. This is shown by: in working on the cracker production process which is still simple and still manual, the number of production of crackers is limited. Provide financial management and accounting training. Based on the priority issues that must be addressed, several solutions that the PKMS team offers to partners are: Production sector by providing the transfer of Appropriate Technology (TTG) in the production process in the form of Blower machines that assist in the frying process and Gerombong, Packaging by providing packaging machines and tools crackers so that the packaging of crackers becomes more hygienic, the Financial Sector by providing training and assistance in making Financial Reports. The results of this PKMS output target are: Increasing the productivity of partners by using cracker production machines, increasing the tidiness and hygiene of cracker packaging and increasing the knowledge of partners in making financial reports.
\end{abstract}

Keywords: product quality, increased production, Appropriate Technology (TTG), financial reporting trainin. 


\section{PENDAHULUAN}

Salah satu prioritas pembangunan dalam Rencana Kerja Pemerintah (RKP) adalah pengembangan Usaha Mikro Kecil dan Menengah (UMKM). Hal ini didasarkan fakta bahwa UMKM telah banyak berkontribusi dalam perekonomian nasional. Pengembangan Usaha Mikro, Kecil dan Menengah (UMKM) menjadi sangat strategis, karena potensinya yang besar dalam menggerakkan kegiatan ekonomi masyarakat, dan sekaligus menjadi tumpuan sumber pendapatan sebagian besar masyarakat dalam meningkatkan kesejahteraannya (Ariani dan Utomo, 2017). Salah satu UMKM yang menjadi mitra pada PKMS ini adalah Usaha Kerupuk Sari Ikan. Pemilik dari Kerupuk Sari Ikan ini adalah Bapak Saepudin. Usaha mitra telah berdisi hampir 20 tahun dimana usaha dari bapak Saepudin adalah dari tahun 2000. Alamat dari Usaha Kerupuk Sari Ikan ini adalah terletak di Desa Sungai Ning Kecamatan Sungai Bungkal Kota Sungai Penuh. Usaha Kerupuk Sari Ikan memperkerjakan 5 orang pekerja (Ana, Wawan, Alex, Syahril, Dadang). Kerupuk ikan adalah produk makanan kering yang dibuat dari tepung pati dan daging ikan dengan penambahan bahanbahan lainnya dan bahan tambahan makanan yang diijinkan (Yuliani dkk, 2018).

Kerupuk merupakan salah satu makanan ringan khas Indonesia yang sangat digemari oleh masyarakat di semua golongan. Pada umumnya kerupuk memiliki bentuk lingkaran dengan diamerer kira-kira $10 \mathrm{~cm}$, dan tipis. Kerupuk memiliki tekstur yang kering dan renyah, dengan berbagai macam variasi rasa. Kerupuk biasanya dijual di dalam kemasan yang belum digoreng. Kerupuk ikan dari jenis yang sulit mengembang ketika digoreng biasanya dijual dalam bentuk sudah digoreng. Jenis-jenis kerupuk yang beredar di masyarakat misalnya kerupuk udang, kerupuk ikan, dan kerupuk bawang. Kerupuk banyak digemari karena harganya yang terjangkau, rasanya yang gurih, dan mudah ditemukan di berbagai daerah, bahkan di pedalaman desa (Utami dkk, 2013).

Kerupuk termasuk kedalam jenis produk industri yang mempunyai potensi cukup baik. Dengan demikian program peningkatan industri mikro kecil berbahan baku krupuk memang perlu dikembangkan karena kegiatan ini mampu memperluas lapangan kerja dan memberikan pelayanan ekonomi yang luas pada masyarakat, tenaga kerja lebih sedikit, sehingga proses produksi lebih banyak, lebih cepat dan lebih efisien. Dengan demikian akan terpenuhi kebutuhan konsumen krupuk (Ratnawati dan Lokajaya, 2020). Kerupuk sangat beragam dalam bentuk, ukuran, bau, warna, rasa, kerenyahan, ketebalan dan nilai gizinya. Perbedaan ini bisa disebabkan pengaruh budaya daerah penghasil kerupuk, bahan baku dan bahan tambahan yang digunakan serta alat dan cara pengolahannya. Komposisi bahan sendiri beserta pengolahannya akan sangat mempengaruhi kualitas kerupuk, dimana komposisi bahan ini juga mempengaruhi pengembangan pada kerupuk tersebut (Hapsari dan Widyastuti, 2018) . Penurunan Omzet Pelaku UMKM dan koperasi akibat covid-19 sangat signifikan Sejak kemunculannya di akhir tahun 2019 (Ratnawati dan Lokajaya, 2020). (UMKM) harus menjadi profesional, produktif, kreatif dan be entrepreneurial (Amri, 2020). 
Pengelolaan keuangan menjadi salah satu aspek penting bagi kemajuan perusahaan. Pengelolaan keuangan dapat dilakukan melalui akuntansi. Akuntansi merupakan proses sistematis untuk menghasilkan informasi keuangan yang dapat digunakan untuk pengambilan keputusan bagi penggunanya. Sepanjang UMKM masih menggunakan uang sebagai alat tukarnya, akuntansi sangat dibutuhkan oleh UMKM (Reni, 2018). Hal yang perlu dilakukan dalam meningkatkan usaha mereka khususnya usaha mikro dan usaha kecil, yang menyebabkan kurang berkembangnya usaha mikro dan kecil antara lain minimnya pemahaman pelaku UMKM tentang akuntansi. Pelaku UMKM pada umumnya hanya melakukan pencatatan sederhana berupa pemasukan dan pengeluaran. Bahkan ada yang tidak mencatat sewa tempat sebagai beban usaha, sehingga usaha terlihat menghasilkan laba yang besar karena beban tidak dicatat sebagaimana mestinya. Akibatnya adalah pencatatan tidak menggambarkan kondisi keuangan usaha yang sesungguhnya. Akuntansi digunakan sebagai standar untuk memudahkan UMKM dalam membuat laporan keuangan yang dapat dipertanggungjawabkan dan dipahami pihak eksternal dan internal (Sulistyowati,2017).

Pada pengabdian yang dilaksanakan oleh Fibrianie yang melaksanapan Pengabdian Kepada Masyarakat mengenai Kerupuk ikan sungai (ikan gabus dan ikan pipih) Mahakam Kalimantan Timur merupakan salah satu makanan khas Kalimantan Timur. Selain untuk di konsumsi seharihari, kerupuk ini juga merupakan salah satu alternatif buah tangan khas Kalimantan Timur. Salah satu contohnya adalah krupuk ikan khas Kotabangun Kalimntan Timur. Dalam pengolahannya, krupuk ikan ini terdiri dari tahapan pengerikan daging ikan sungai, penggilingan daging ikan, pencampuran bahan, perebusan adonan, penjemuran, pemotongan kerupuk. Masalah dalam pengolahan kerupuk ini adalah pada pemotongan adonan kerupuk masih manual, dan peletakan mesin giling dan alat potong kerupuk berjauhan sehingga tidak efisien waktu dalam pengolahannya. Dengan metode preliminary, process design, final design dan prototyping dihasilkan rancangan mesin giling dan mesin potong kerupuk (Fibriane dkk,2016).

Sarwono telah melakukan PKM pada Kelompok Pengolah dan Pemasar (Poklahsar) Sumber Rezeki dan Nusa Damai di Desa Kuala Secapah adalah kelompok wanita yang bergerak dalam industri Rumah Tangga skala kecil yang mengolah hasil perikanan dan laut menjadi produk olahan seperti kerupuk ikan dan ikan asin. Dengan hasil dari target luaran dalam kegiatan ini adalah dibuatnya teknologi mesin pemotongan dan teknologi mesin penyimpan bahan baku (chest freezer) untuk produksi kerupuk ikan, dibuatnya produksi kerupuk ikan dan ikan asin dengan berbagai aneka bentuk kerupuk dan jenis ikan serta dibuatnya kemasan produk ikan asin \& kerupuk ikan yang menarik, dan memiliki PIRT, komposisi bahan, kandungan gizi, tanggal produksi dan expired produk (Sarwono dkk, 2018). 


\section{METODE PELAKSANAAN}

\section{Prosedur Kerja}

Berdasarkan permasalahan prioritas yang harus ditangani maka metode kerja tim PKMS kepada mitra adalah:

\section{a) Bidang produksi}

Dengan Memberikan transfer Teknologi Tepat Guna (TTG) dalam proses produksi berupa mesin Blower yang membantu dalam proses penggorengan dan Gerombong

\section{b) Bidang Pelatihan}

Dengan memberikan pelatihan kepada mitra mengenai Mengenai Manajemen Keuangan dan Akuntansi

\section{Mekanisme Pelaksanaan}

Rencana kegiatan yang menunjukan langkah-langkah dalam pengabdian ini yaitu:

\section{a) Tahap Analisis Situasi dan Kondisi Mitra}

Pada tahap ini tim pelaksana melalukan survey, pengumpulan data dan identifikasi masalah mitra, serta melakukan Focus Group Discussion (FGD) dengan mitra untuk jadwal pelaksanaan kegiatan PKMS.

\section{b) Tahap Persiapan dan Pembuatan TTG}

Persiapan difokuskan dengan menyiapkan semua peralatan yang dibutuhkan untuk melaksanakan kegiatan dan pembuatan Teknologi Tepat Guna (TTG) pada proses produksi kerupuk

\section{c) Tahap Pelatihan}

Pada tahap ini Tim pelaksana akan memulai kegiatan pelatihan sesuai dengan jadwal yang sudah ditentukan dan disepakati bersama dengan mitra.

\section{HASIL DAN PEMBAHASAN}

Gambaran usaha mitra sebelum adanya dukungan peralatan yang dilakukan oleh tim PKM, antara lain :
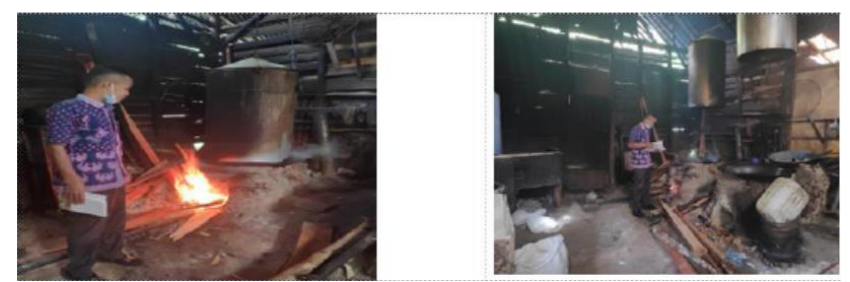

Gambar 1. Pengamatan, Observasi Dan Wawancara Tim Pengusul PKMS Dengan Mitra 


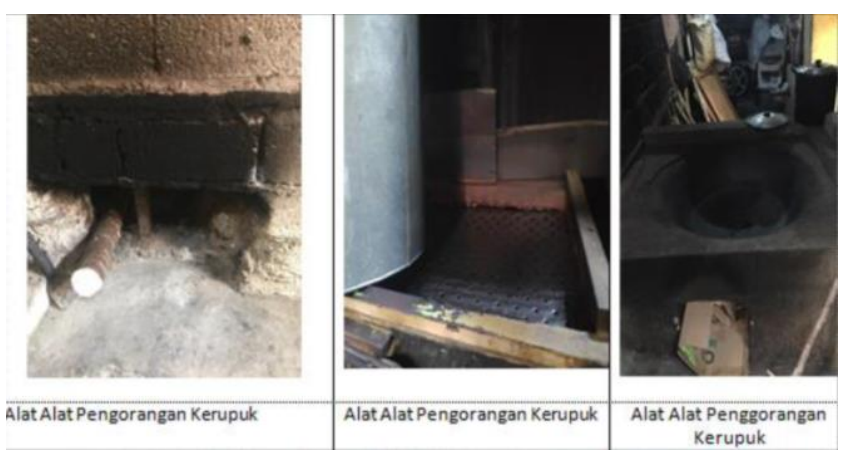

Gambar 2. Alat-Alat Pada Proses Produksi

Pada proses pengolahan produk yang perlu dijaga dan diperhatikan adalah proses produksi yang efektif dan efisien agar hasil dari produk yang diproduksi dapat diterima dengan baik oleh konsumen. Proses pengolahan yang menjadi pengendalian dan dapat mempengaruhi kerenyahan kerupuk yaitu proses pencampuran bahan pemotongan, pengeringan dan penggorengan.

\section{a) Pencampuran bahan}

Proses pencampuran dilakukan pada tahap pengadonan yaitu dilakukan proses pencampuran daging ikan giling, tapioka, dan bumbu-bumbu lalu diaduk sampai menjadi kalis atau siap dicetak. Komposisi bahan yang dicampurkan telah terstandard sesuai dengan resep yang dimiliki pengusaha.

\section{b) Pengukusan}

Pengukusan dilakukan sampai seluruh bagian matang atau tergelatinasi dengan baik.

\section{c) Pemotongan}

Proses pemotongan kerupuk dilakukan untuk mendapatkan kerupuk yang tipis dan memiliki ukuran yang homogen. Tebal tipisnya kerupuk mempengaruhi kerenyahan produk kerupuk.

\section{d) Pengeringan}

Pengeringan merupakan salah satu faktor penting yang sangat menentukan kualitas kerenyahan kerupuk. Kerupuk yang dikeringkan harus kering merata. Pengeringan mengandalkan sinar matahari.
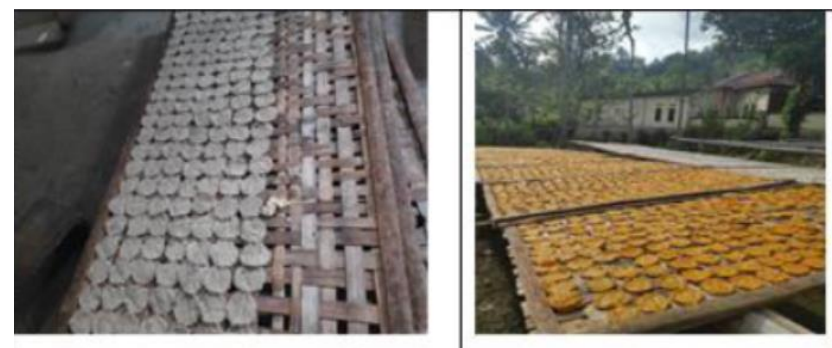

Gambar 3. Proses Pengeringan 
Seminar Nasional Penelitian dan Pengabdian kepada Masyarakat Universitas Sang Bumi Ruwa Jurai Tahun 2021

Untuk memfasilitasi pada proses produksi dan pelatihan maka oleh Tim Pengabdian telah melaksanakan hal di bawah ini:

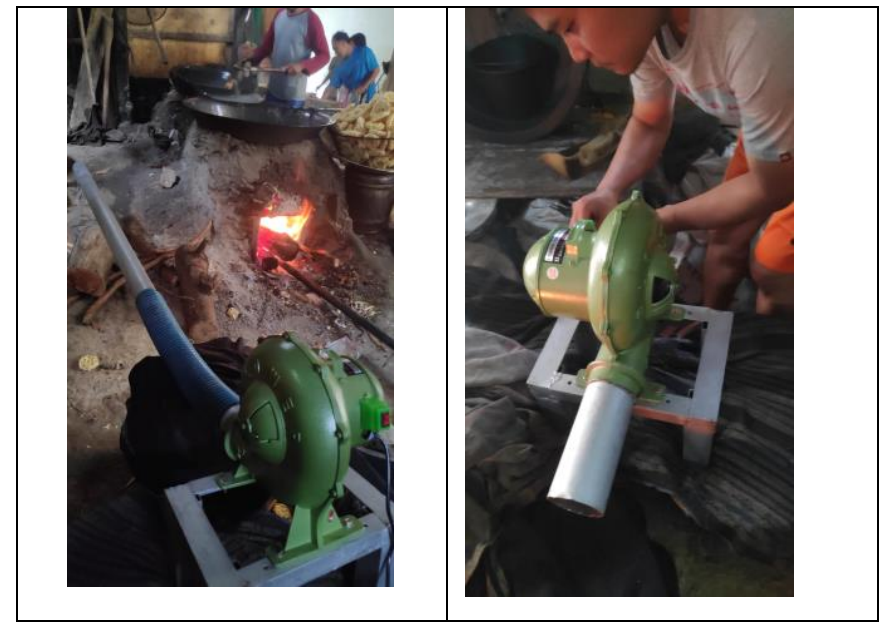

Gambar 4. Mesin Blower

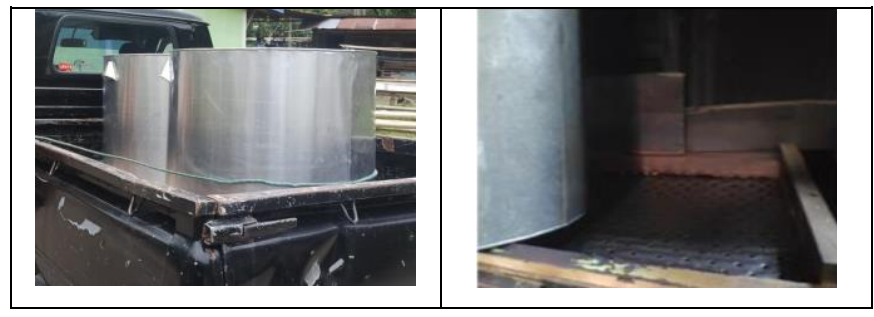

Gambar 5. Gerombong

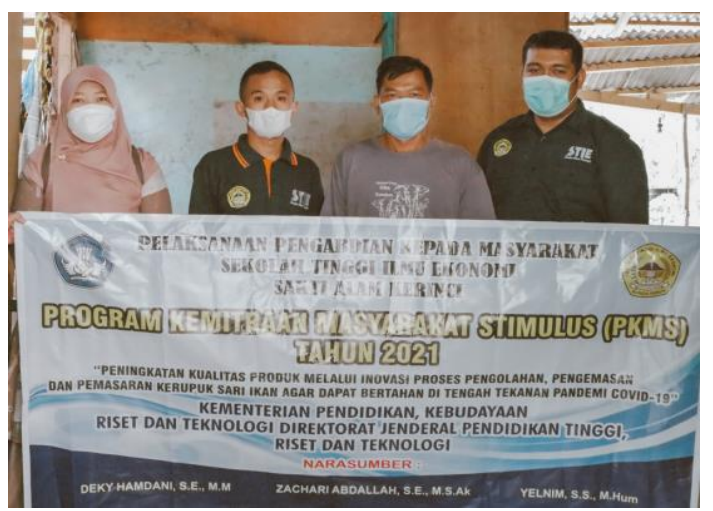

Gambar 6. Kegiatan PKMS

\section{KESIMPULAN}

Dari kegiatan pengabdian masyarakat yang telah dilakukan, terdapat beberapa kesimpulan: 1) Dalam mendeteksi kendala yang dialami pada mitra, motode survei, observasi dan wawancara sangat efektif sekali. 2) Materi pelatihan dapat disesuaikan dengan kebutuhan serta tingkat 
pendidikan peserta pelatihan yang merupakan pekerja di mitra. 3) Mengevaluasi dan memonitoring setiap kegiatan pengabdian masyarakat yang dilakukan, sehingga menjadi tahu apakah masih terdapat kendala yang dihadapi pada mitra.

\section{Saran}

Saran dari pelaksanaan kegiatan pengabdian masyarakat ini adalah kendala yang masih dihadapi oleh UKM mitra hendaknya diperhatikan untuk dijadikan bahan kajian pelaksanaan pengabdian masyarakat selanjutnya, serta pihak pelaksana pengabdian masyarakat dapat terus secara kontinyu melakukan evaluasi dan monitoring terhadap keberlanjutan penggunaan alat yang sudah diintroduksi dan ditransfer kepada mitra.

\section{UCAPAN TERIMA KASIH}

Penulis mengucapkan terima kasih kepada Kementerian Pendidikan, Kebudayaan Riset, Dan Teknologi Direktorat Jenderal Pendidikan Tinggi, Riset, Dan Teknologi yang telah memberi dukungan moral dan dana terhadap program pengabdian masyarakat ini ini.

\section{DAFTAR PUSTAKA}

A. Ariani and M. N. Utomo, "Kajian Strategi Pengembangan Usaha Mikro Kecil Dan Menengah (Umkm) Di Kota Tarakan," J. Organ. dan Manaj., vol. 13, no. 2, pp. 99-118, 2017, doi: 10.33830/jom.v13i2.55.2017.

Y. Yuliani, M. Marwati, H. Wardana, A. Emmawati, and K. P. Candra, "Karakteristik Kerupuk Ikan Dengan Substitusi Tepung Tulang," Jphpi, vol. 21, no. 2, pp. 258-265, 2018.

E. T. Utami, Mahriani, and E. Utarti, "Inovasi Formulasi Adonan Pembuatan Kerupuk Ikan Dengan Penambahan Tepung Ubi Jalar (Ipomoea batatas) : Upaya Peningkatan Kualitas Dan Produktivitas Usaha Home Industry Kerupuk Ikan Di Desa Jangkar Situbondo," Jur. Biol. FMIPA Univ. Jember Abstr., 2013.

T. Ratnawati and N. Lokajaya, "Pkm Teknologi Tepat Guna Manajemen Kelompok Industri Kecil Krupuk Desa Ujung Pangkah Kabupaten Gresik,” J. Community Serv. Consort., vol. 1, no. 1, pp. 99-110, 2020.

D. I. Hapsari and E. Widyastuti, "Inovasi Produk Makanan Olahan Melalui Pembudidayaan Belut Dan Ikan Lele Serta Pemanfaatan Limbah Tulang Ikan," Abdimas Unwahas, vol. 3, no. 1, pp. 40-45, 2018, doi: 10.31942/abd.v3i1.2238.

A. Amri, "Pengaruh Periklanan Melalui Media Sosial Terhadap UMKM di Indonesia di Masa PAndemi," J. Brand, vol. 2, no. 1, pp. 123-130, 2020, [Online]. Available: https://www.academia.edu/42672824/Dampak_Covid-

19_Terhadap_UMKM_di_Indonesia.

Reni Fatwitawati SE, "Pengelolaan Keuangan Bagi Usaha Mikro Kecil Menengah (Umkm) Di Kelurahan Airputih Kecamatan Tampan Kota Pekanbaru," SEMBADHA, vol. 01, no. 01, pp. 
225-229, 2018.

Y. Sulistyowati, "Listing Registration Of Sme Financial Reporting (A Case Studi In Malang)," J. Ilmu Manaj. dan Akunt., vol. 5, no. 2, pp. 49-55, 2017.

E. Fibrianie, D. Cahyadi, and A. farid Hidayanto, "Rancang Bangun Mesin Pengolah Kerupuk Ikan Khas Sungai Kalimantan Timur,” J. Tek. Ind. UIN SUSKA, vol. 2 Nomor 2, no. 1, pp. 162-166, 2016.

E. Sarwono, A. Sutarmin, U. Ruhama', L. Suwarni, and S. Selviana, "PKM Inovasi Teknologi Produksi Olahan Ikan Pada Poklahsar Desa Kuala Secapah,” JPP IPTEK (Jurnal Pengabdi. dan Penerapan IPTEK), vol. 2, no. 2, pp. 27-34, 2018, doi: 10.31284/j.jppiptek.2018.v2i2.307. 